\title{
Effects of neutral detergent fiber concentration of sugarcane-based diets on the performance of Holstein heifers
}

\section{Efeito do nível dietético de FDN de cana-de-açúcar sobre o desempenho de novilhas Holandesas}

\author{
Paulo Celso da Silva Gallo ${ }^{1 *}$; Marcos Neves Pereira ${ }^{2}$; Giuliano Pavani de Campos ${ }^{1}$; \\ Sarita Bonagurio Gallo 3
}

\begin{abstract}
This study aimed to evaluate the effects of increasing the neutral detergent fibers (NDF) concentration of sugarcane-based diets on the growth and development of Holstein heifers. Twenty-seven Holstein heifers with a mean body weight of $265.5 \pm 36.4 \mathrm{~kg}$ were housed in a sand bedded tie stall and fed individually. The experimental diet consisted of fresh sugarcane and concentrate. Three concentrations of sugarcane NDF were compared: 33\% (SC33), 38\% (SC38), and 42\% (SC42). Crude protein content of experimental diets was $16 \%$. The following parameters were evaluated: dry matter intake, weight gain and morphometric measures, digestibility, feeding behavior, and ruminal $\mathrm{pH}$. The experimental design was a randomized block and all analyses were performed using the MIXED procedure in SAS. Intake of DM decreased as NDF concentration increased $(\mathrm{p}=0.07)$, but weight gain and growth were not significantly affected $(\mathrm{p}=0.74)$. As dietary NDF increased, chewing activity per unit DM intake increased $(\mathrm{p}=0.001)$, but rumen $\mathrm{pH}$ was not significantly affected $(\mathrm{p}=0.91)$. Diets formulated with $330-420 \mathrm{~g}$ of sugarcane NDF/ $\mathrm{kg}$ of dry matter were sufficient to support the growth of Holstein heifers. Key words: Behavior. Growth. Digestibility. Nutrition.
\end{abstract}

\section{Resumo}

O objetivo foi avaliar dietas com diferentes teores de FDN oriundos de cana-de-açúcar no crescimento e desenvolvimento de novilhas Holandesas. Os animais experimentais foram vinte e sete novilhas da raça Holandesa pesando em média 265,5 $\pm 36,4 \mathrm{~kg}$, alojadas em um Tie Stall com camas de areia e alimentadas individualmente. A ração experimental total era composta por cana-de-açúcar e concentrado. Testou três concentrações dietéticas de FDN oriundo da cana-de-açúcar: 33\% de FDN (SC33); 38\% FDN (SC38) e $42 \%$ FDN (SC42). O teor de proteína bruta da ração foi de 16\%. Foram avaliados consumo de matéria seca, ganho de peso e parâmetros corporais, digestibilidade, comportamento alimentar e pH ruminal. O delineamento foi em blocos casualizados, e a analise estatísticas pelo proc MIXED do programa SAS. O consumo de matéria seca foi menor com o aumento de $\mathrm{FDN}$ da dieta $(\mathrm{P}=0,07)$, mas isso não interferiu no ganho de peso e crescimento dos animais $(\mathrm{P}=0,74)$. A maior inclusão de FDN na ração resultou em aumento na atividade mastigatória por unidade de matéria seca ingerida $(\mathrm{P}=0,001)$ e não interferiu no $\mathrm{pH}(\mathrm{P}=0,91)$. Pode-se concluir que rações formuladas com até 420 gramas de FDN oriundo de cana-deaçúcar por $\mathrm{kg}$ de matéria seca dietética foram adequadas à fase de crescimento de novilhas Holandesas. Palavras-chave: Comportamento. Crescimento. Digestibilidade. Nutrição.

1 Pesquisadores, Nutron, Cargill Animal Nutrition Brasil, Campinas, SP, Brasil. E-mail: paulogallo1@icloud.com; giuliano_ campos@cargill.com

2 Prof., Universidade Federal de Lavras, UFLA, Lavras, MG, Brasil. E-mail: mpereira@dzo.ufla.br

3 Prof ${ }^{\text {a }}$, Faculdade de Zootecnia e Engenharia de Alimentos, Universidade de São Paulo, USP, Pirassununga, SP, Brasil. E-mail: saritabgallo@usp.br

* Author for correspondence 


\section{Introduction}

Dairy heifer rearing involves significant financial input accounting for a large proportion of total onfarm costs, and shortening the pre-weaning period may affect long-term profit potential (CURTIS et al., 2018). Early life nutrition must ensure that animals are sufficiently well grown to calve down at around 24 months of age. Below this age, heifers are considered unlikely to have sufficient body size to support their potential for lifetime milk production or to easily deliver a healthy calf (ETTEMA; SANTOS, 2004). Conversely, rearing costs will be increased for animals with a greater age at first calving (AFC).

Establishing minimum standards of morphometric measures that animals are to achieve at age at first calving is challenging because of genetic variation between lineages within the same breed. Post-weaning, heifers should be provided with a diet that allows growth at a sufficient rate without fattening; a growth rate of between 0.8$0.9 \mathrm{~kg}$ per day (DRACKLEY, 2008) and, in terms of body composition, ensuring animals reach a minimum withers height of $125 \mathrm{~cm}$ (CURTIS et al., 2018). However, reproductive parameters have been shown to be associated with plane of nutrition in a study where dairy heifers were fed an accelerated feeding regime (1.0 kg/day weight gain) from early life to puberty (LAMMERS et al., 1999). According to Keown and Everett (1986), early life nutrition must ensure that animals achieve a body weight of approximately $550 \mathrm{~kg}$ to calve down at around 24 months of age. To achieve these targets with a reduced financial investment, the forage source must support adequate performance while reducing the proportion of concentrate in the diet to a minimum.

Brazil is the world's largest producer of sugarcane (CAETANO et al., 2016), a crop of which management is widely known by dairy producers. Sugarcane has several positive characteristics including large dry matter yields/ha (LASCANO et al., 2012; MARIZ et al., 2013) and low cropping requirements. It can be cultivated in areas with rugged topography, but must be harvested frequently to be used as fresh forage. This study aimed to evaluate the effects of increasing the neutral detergent fiber (NDF) concentration of sugarcane-based diets on the growth and development of Holstein heifers.

\section{Material and Methods}

This study was conducted in Ijaci, Minas Gerais, Brazil, using 27 Holstein heifers with a mean body weight of $265.5 \pm 36.4 \mathrm{~kg}$. Heifers were housed in a sand bedded tie stall and fed individually once daily a complete feed consisting of concentrate and sugarcane variety RB $72-454$ as the sole source of forage to allow for a $15 \%$ refusal rate. Fresh sugarcane was harvested and chopped daily without removal of the rind or the tops and added to the concentrate at feeding time.

A 14-day pre-experimental period was used for adaptation to the experimental diet, when heifers were fed an adaptation diet consisting of 38\% sugarcane NDF and $16 \%$ crude protein (Tables 1 and 2). On days 13 and 14 of the adaptation period the live weight, withers height, rump height, abdomen girth, dry matter intake, and chewing activities of each heifer were recorded and later included as covariates in the statistical models.

At the end of the adaptation period, heifers were allocated by live weight into nine blocks of three heifers each and randomly assigned to one of three dietary treatments for the 56-day trial period (Table 2 ). Diets were formulated to provide the following concentrations of sugarcane NDF: 33 (SC33), 38 (SC38), and 42\% (SC42) (dry matter basis). The amount and quality of crude protein (16\%) were kept constant across diets by using only corn protein and soybean meal in the formulations. 
Table 1. Chemical composition of sugar cane and concentrates of experimental treatments with $33 \%$ of NDF (SC33), $38 \%$ of NDF (SC 38 ) and with $42 \%$ of NDF (SD42) originating from sugar cane.

\begin{tabular}{lcccc}
\hline & Sugar cane & SC33 & SC38 & SC42 \\
\hline Dry matter (\%) & 29,6 & 87,6 & 87,3 & 88,4 \\
Crude protein (\%DM) & 2,9 & 35,0 & 44,3 & 58,0 \\
Neutral detergent fiber (\%DM) & 54,2 & 8,7 & 8,0 & 8,4 \\
Acid detergent fiber (\%DM) & 26,6 & 5,6 & 6,1 & 7,2 \\
Etheric extract (\%DM) & 0,72 & 3,6 & 4,4 & 4,2 \\
Ash (\%DM) & 2,5 & 4,7 & 8,5 & 7,2 \\
Non fiber carboidrates (\%DM) & 39,7 & 48,0 & 34,8 & 22,2 \\
Calcium (\%DM) & 0,32 & 0,95 & 1,15 & 1,51 \\
Phosphorus (\%DM) & 0,12 & 0,66 & 0,82 & 1,05 \\
\hline
\end{tabular}

$\mathrm{NFC}=$ non fiber carboidrates $=100-($ crude protein + acid detergent fiber + ash + etheric extract $)$.

Table 2. Experimental rations with $33 \%$ of NDF (SC33), 38\% of NDF (SC 38) and with $42 \%$ of NDF (SD42) originating from sugar cane.

\begin{tabular}{lccc}
\hline & SC33 & SC38 & SC42 \\
\hline Ingredient (as-fed) (\%) & & 69,9 & 78,0 \\
Sugar cane & 61,6 & 12,2 & 2,4 \\
Fine Ground Corn & 21,8 & 8,8 & 10,3 \\
Soybean meal & 7,6 & 6,5 & 6,7 \\
Corn gluten & 6,4 & 1,1 & 1,1 \\
Urea & 1,1 & 0,2 \\
Mineral & 0,2 & 0,2 & 0,7 \\
Premix mineral ${ }^{1}$ & 0,7 & 0,1 & 0,1 \\
Premix vitamin ${ }^{2}$ & 0,1 & 0,3 \\
Bicalcico phosphate & 0,1 & 0,2 & 0,2 \\
Limestone & 0,4 & & 35,4 \\
Nutrient Composition & & 37,6 & 15,9 \\
Dry matter (\%) & 40,4 & 16,1 & 44,1 \\
Crude protein (\% of DM) & 15,7 & 40,3 & 42,3 \\
Total Neutral detergent fiber (\% of DM) & 36,8 & 37,9 & 19,8 \\
Sugar cane Neutral detergent fiber (\% of DM) & 33,4 & 17,6 & 0,8 \\
Acid detergent fiber (\% of DM) & 16,8 & 0,9 & 2,9 \\
Etheric extract (\% of DM) & 1,2 & 3,3 & 36,3 \\
Ash (\% of DM) & 2,1 & 39,4 & 0,8 \\
Non fiber carboidrates (\% of DM)* & 44,2 & 0,7 & 0,7 \\
Calcium (\% of DM) & 0,8 & 0,7 & \\
Phosphorus (\% of DM) & 0,7 & & \\
\hline
\end{tabular}

$* \mathrm{NFC}=$ Non fiber carboidrates $=100-($ crude protein + Neutral detergent fiber + ash + etheric extract $)$.

1-Premix Mineral (por kg)= Ca (180 g), P (130 g), Cu (1250 mg), Zn (5270 mg), Mn (2000 mg), I (90 mg), Co (100 mg), Se (15 $\mathrm{mg})$, Fe (2200 mg) e F (130 mg).

2-Premix Vitaminic (por kg) = Vit. A (15.000.000 UI), Vit D (2.000.000 UI) e Vit. E (12.000 mg). 
Sugarcane, concentrate, and refusals samples from each heifer were collected twice weekly, frozen, and composited for analysis of dry matter (DM), crude protein (CP) (AOAC, 1990), acid detergent fiber (ADF), and NDF (VAN SOEST et al., 1991).

The live weight, abdomen girth, and height at the withers and rump of each heifer were recorded every seven days. Daily changes of body weight and other morphometric measures were calculated for each week in the eight-week trial period by the difference between the measures from two subsequent sevenday intervals. Live weight was recorded using a scale (500 kg capacity) and the height at the withers and rump ( $\pm 1.0 \mathrm{~cm}$, Graduated stick) was recorded at the dorsal end of the spinous process of the third thoracic vertebra (at the withers) and at the highest point of the sacrum bone, respectively. Abdomen girth $( \pm 1 \mathrm{~cm})$ was measured immediately from the caudal to the thoracic limbs using a tape measure.

From day 44 to $55, \mathrm{Cr}_{2} \mathrm{O}_{3}$ was administered (10.0 $\mathrm{g}$ /day) via gelatin capsules into the rumen with an oral cannula twice daily for the estimation of total tract apparent digestibilities (WILLIAMS et al., 1962). Fecal sampling commenced on the morning of day 54 at the time of the procedure at 2-h intervals for two days; feed refusals were sampled once daily on days 54 and 55 and a composite sample was made for each heifer. Samples of feed offered and refused and fecal samples were analyzed for DM, $\mathrm{CP}, \mathrm{ADF}$, and NDF as described above.

Fecal output was determined using $\mathrm{Cr}_{2} \mathrm{O}_{3}$ as a marker for the estimation of fecal output (WILLIAMS et al., 1962). Briefly, $1.0 \mathrm{~g}$ of dried ground fecal sample from each calf was ashed for $8 \mathrm{~h}$ in a muffle furnace at $550{ }^{\circ} \mathrm{C}$, digested in $3 \mathrm{ml}$ of phosphoric acid-manganese sulphate solution (30 $\mathrm{ml}$ of $10 \%, \mathrm{w} / \mathrm{v}, \mathrm{MnSO}_{4} \cdot 4 \mathrm{H}_{2} \mathrm{O}$ solution in $1,000 \mathrm{ml}$ of $85 \%$ phosphoric acid) and $4 \mathrm{ml}$ of $4.5 \%(\mathrm{w} / \mathrm{v})$ potassium bromate solution, and heated on a sand bath until a purple color developed. The digests were then transferred to $100-\mathrm{ml}$ volumetric flasks containing $25 \mathrm{ml}$ of a calcium chloride solution
$(4,000 \mathrm{ppm})$ and made to volume with deionized water. Next, the mixture was filtered on Whatman ${ }^{\mathrm{TM}}$ grade 40 filter paper, read on an AA-100 atomic absorption spectrophotometer (Varian Medical Systems, Palo Alto, CA, USA), and compared to standards containing $0,4.0,8.0,15.5$, and 31.25 ppm of chromium.

Chewing activity of each heifer was measured by visual observation of feeding behavior at 5 -min intervals for $24 \mathrm{~h}$ continuously on day 14 of the adaptation period (covariate) and day 28 of the trial period. The recorded chewing activities included time spent eating, drinking, ruminating, or resting (lying or standing). The daily chewing time was estimated as the sum of daily eating time and daily rumination time (min/day). The chewing, eating, and rumination times per unit DM intake were calculated using DM intake data from the two 24-h observation periods. The chewing activity per digestible organic matter intake (DOMI) was calculated using the organic matter digestibility (OMD) coefficient estimated for each heifer on days 54 and 55 of the experimental period (SIÉCOLA JÚNIOR et al., 2014).

Ruminal $\mathrm{pH}$ was measured $10 \mathrm{~h}$ after feeding from samples of fluid obtained by percutaneous needle aspiration from the caudoventral rumen (rumenocentesis) (GARRETT et al., 1999); heifers were given free access to feed during collection. A $10-\mathrm{cm}^{2}$ area located $12-15 \mathrm{~cm}$ caudoventral to the last rib was identified, scrubbed with a povidoneiodine scrub, and wiped with $70 \%$ isopropyl alcohol. A $16 \mathrm{~g} \times 125-\mathrm{mm}$ needle was inserted into the ventral rumen and a syringe was used to aspirate a minimum of $3 \mathrm{ml}$ of fluid. The $\mathrm{pH}$ of the fluid was determined immediately using a portable $\mathrm{pH}$ meter (pH-Meter CG 837, Schott Instruments GmbH, Mainz, Germany).

The particle size distribution of chopped sugarcane was determined from fresh composite samples constructed from eight samples of equal volume collected weekly during the experimental period. Samples were separated into three particle fractions 
$(>19.0,>8.0$, and $<8.0 \mathrm{~mm}$ ) using a Penn State particle separator (PSPS) (LAMMERS et al., 1996) and DM content was determined for each fraction.

The live weight, DM intake, rump height, withers height, and abdomen girth of each heifer were recorded weekly and analyzed as repeated measures using the MIXED procedure in SAS statistical software (1995). The covariance structure used was identified by the highest Akaike information criterion (AIC) for models run under compound symmetry, unstructured, and first order autoregressive covariance structures.

The mean square error for heifer identity nested within treatment was used to test for treatment effects. The degrees of freedom for treatment were partitioned into two orthogonal contrasts each with a single degree of freedom: the linear (SC33 $\times$ $\mathrm{SC} 42)$ and quadratic $(\mathrm{SC} 38 \times \mathrm{SC} 33+\mathrm{SC} 42)$ effects of increasing the NDF concentration of sugarcanebased diets. Daily live weight gain, height, and abdomen girth were analyzed in the same model but without the covariate term.
The apparent digestibility of NDF and ruminal $\mathrm{pH}$ were analyzed using the MIXED procedure. The frequency distribution of ruminal $\mathrm{pH}$ values above 5.8, between 5.8 and 5.5, and below 5.5 was compared by the Chi-square test using the FREQ procedure in SAS. The three $\mathrm{pH}$ cut-off points were set without examining the data.

\section{Results}

Intake of DM decreased $(\mathrm{p}=0.07)$ as NDF concentration increased from $33 \%$ to $42 \%$ in sugarcane diets (Table 2) over the eight-week experimental period (Table 3). Increasing dietary NDF concentration of sugarcane diets did not affect body weight as measured by live weight and abdomen girth adjusted for the covariate or daily weight and abdomen girth gain (Table 3). heifers gained weight in a linear fashion during the experimental period. There were no significant dietary treatment differences in withers and rump height adjusted for the covariate and daily rump height gain.

Table 3. Performance of heifers fed with $33 \%$ of NDF (SC33), 38\% of NDF (SC 38) and with 42\% of NDF (SD42) originating from sugar cane.

\begin{tabular}{lccccccccc}
\hline & C33 & C38 & C42 & SEM & TRAT & SEM & T*S & L & Q \\
\hline Dry matter intake (kg/d) & 7,4 & 6,8 & 6,6 & 0,27 & 0,17 & $<0,001$ & 0,07 & 0,07 & 0,62 \\
Dry matter intake (\% PV) & 2,48 & 2,26 & 2,26 & 0,09 & 0,19 & $<0,001$ & 0,10 & 0,11 & 0,36 \\
Body weight (kg) & 298,0 & 297,8 & 292,3 & 2,7 & 0,26 & $<0,001$ & 0,55 & 0,15 & 0,43 \\
Daily weight gain (kg/d) & 1,002 & 0,979 & 0,951 & 0,150 & 0,94 & $<0,001$ & 0,30 & 0,74 & 0,98 \\
Thoracic perimeter (cm) & 147,2 & 147,0 & 147,0 & 0,3 & 0,89 & $<0,001$ & 0,25 & 0,67 & 0,82 \\
Perimeter gain (cm/d) & 0,095 & 0,085 & 0,091 & 0,016 & 0,91 & $<0,001$ & 0,18 & 0,87 & 0,70 \\
Withers height (m) & 1,19 & 1,20 & 1,20 & 0,36 & 0,30 & $<0,001$ & 0,80 & 0,52 & 0,18 \\
Withers gain (cm/d) & 0,061 & 0,084 & 0,072 & 0,007 & 0,12 & $<0,01$ & 0,55 & 0,28 & 0,07 \\
Hip height (m) & 1,23 & 1,23 & 1,23 & 0,33 & 0,98 & $<0,001$ & 0,62 & 0,85 & 0,98 \\
Hip gain $(\mathrm{cm} / \mathrm{d})$ & 0,049 & 0,043 & 0,045 & 0,005 & 0,77 & $<0,001$ & 0,90 & 0,64 & 0,59 \\
\hline
\end{tabular}

$\mathrm{DM}=$ dry matter. $\mathrm{SEM}=$ standard error, TRAT $=\mathrm{P}$ for the week effect, $\mathrm{T} * \mathrm{~W}=\mathrm{P}$ to the interaction between treatment and week, $\mathrm{L}$ $=\mathrm{P}$ to the linear contrast of sugar cane inclusion level, $\mathrm{Q}=\mathrm{P}$ to the quadratic contrast of sugar cane inclusion level.

Because the concentrate used in this study was virtually fiber-free, the digestibility of dietary NDF reflects the sugarcane NDF digestibility. However, fecal sample collections were made at 2-h intervals continuously for two days, which may have depressed fecal output and artificially inflated apparent digestibility values (Table 4). 
Table 4. Apparent digestibility of the nutritional components of the experimental rations with $33 \%$ of NDF (SC33), $38 \%$ of NDF (SC 38 ) and with $42 \%$ of NDF (SD42) originating from sugar cane.

\begin{tabular}{lccccccc}
\hline & SC33 & SC38 & SC42 & SEM & TRAT & L & Q \\
\hline DDM (\%) & 73,9 & 70,7 & 75,4 & 2,9 & 0,51 & 0,71 & 0,28 \\
DOM (\%) & 75,7 & 73,0 & 77,0 & 2,7 & 0,57 & 0,74 & 0,32 \\
DNDF (\%) & 55,0 & 50,0 & 59,7 & 4,9 & 0,40 & 0,50 & 0,24 \\
DMONFDN (\%) & 88,3 & 87,5 & 90,1 & 1,2 & 0,35 & 0,33 & 0,28 \\
\hline
\end{tabular}

Apparent digestibility (\%) of the dry matter (DDM), organic matter (DOM), NDF (DNDF) and non-ndf organic matter (DMONNDF). $\mathrm{SEM}=$ Standard error of the average, TRAT $=\mathrm{p}$ for the treatment effect, $\mathrm{L}=\mathrm{p}$ for the linear Contrast of sugar cane inclusion level, $\mathrm{Q}=\mathrm{p}$ for the quadratic contrast of sugar cane inclusion level.

The mean percentage of sugarcane particles $>19.0 \mathrm{~mm}$ was less than $10 \%$ (Table 5). Daily chewing time per unit DM intake was positively associated with concentration of NDF in sugarcane diets (Table 6).
Mean ruminal fluid $\mathrm{pH}$ was $6.19,6.12$, and 6.16 for heifers fed 33-, 38-, and 42\%-NDF sugarcane diets, respectively, but there was no significant difference in ruminal $\mathrm{pH}$ between dietary treatments.

Table 5. Sugar cane particle size.

\begin{tabular}{lcc}
\hline & \% as fed & \% DM \\
\hline High $(>190 \mathrm{~mm})$ & 6,9 & 9,1 \\
Medium $(190 \mathrm{a} 78 \mathrm{~mm})$ & 42,9 & 43,3 \\
Low $(<78 \mathrm{~mm})$ & 50,2 & 47,6 \\
\hline
\end{tabular}

Determined by the particle-holder of the "Penn State" (LAMMERS et al.,1996).

Table 6. Time of rumination, ingestion and chewing $(\mathrm{min} / \mathrm{d})$ and these parameters per kg of consumption of dry matter $(\mathrm{min} / \mathrm{CMS}$ ) of experimental diets with $33 \%$ of NDF (SC33), 38\% of NDF (SC 38) and with $42 \%$ of NDF (SD42) originating from sugar cane.

\begin{tabular}{|c|c|c|c|c|c|c|c|}
\hline & SC33 & $\mathrm{SC} 38$ & $\mathrm{SC} 42$ & SEM & TRAT & $\mathrm{L}$ & Q \\
\hline \multicolumn{8}{|c|}{$\min / d$} \\
\hline Intake & 222 & 242 & 245 & 11 & 0,31 & 0,16 & 0,55 \\
\hline Rumination & 439 & 491 & 477 & 35 & 0,56 & 0,45 & 0,45 \\
\hline \multicolumn{8}{|c|}{$\mathrm{min} / \mathrm{DMI}$} \\
\hline Intake & 32,7 & 39,1 & 44,2 & 1,9 & $<0,01$ & $<0,001$ & 0,80 \\
\hline Rumination & 67,2 & 80,5 & 85,7 & 6,1 & 0,12 & 0,05 & 0,60 \\
\hline Chewing & 100,0 & 119,4 & 129,9 & 7,2 & 0,03 & 0,01 & 0,63 \\
\hline
\end{tabular}

$\mathrm{EPM}=$ Standard error of the mean, TRAT $=\mathrm{P}$ for treatment effect, $\mathrm{L}=\mathrm{P}$ for linear contrast of sugar cane, $\mathrm{Q}=\mathrm{P}$ for the quadratic contrast of level of inclusion of sugarcane. 


\section{Discussion}

The use of sugarcane in heifer diets provides sufficient energy to support growth at reduced cost both in cattle raised for dairy and meat production (REYES et al., 2014; MORAES et al., 2015). It is safe to conclude that increasing dietary NDF concentration of sugarcane diets from 33 to $42 \%$ did not significantly affect the height of dairy heifers.

Under similar experimental conditions, Andrade and Pereira (1999) reported that DM intake decreased $(\mathrm{p}=0.09)$ when corn silage was replaced with sugarcane in Holstein heifer diets. Salah et al. (2015) reported that DM intake and weight gain decreased significantly when dietary NDF concentration increased by $10 \%$. Even though the inclusion of nitrogen-rich concentrates results in a significant increase in sugarcane intake by ruminants compared to supplementation with nonprotein nitrogen sources only (LASCANO et al., 2012), the formulation of high-energy diets for improved animal performance may not completely eliminate the inhibitory effect of sugarcane on DM intake.

An optimal age at first calving of 24 months at a target body weight of $550 \mathrm{~kg}$ was set by the farm management as minimum standards for Holstein heifers (KEOWN; EVERETT, 1986). In the current study, live weight gain in the three dietary treatments was higher than that required to achieve that target. Similar results were reported by Andrade and Pereira (1999) when replacing corn silage with sugarcane in heifer diets. Conversely, Rangel et al. (2010) reported that growth rates were lower in heifers fed sugarcane diets, but the differences between the studies are due to the type of supplement provided with the sugarcane forage.

Despite the lack of statistical power to detect treatment effects on apparent digestibility coefficients of DM and NDF (Table 4), the values were higher for heifers fed the $42 \%$-NDF sugarcane diet (SC42). This result may be explained by the higher digestibility of sugarcane sucrose compared to that of cornstarch in the concentrate (ANDRADE; PEREIRA, 1999; CORREA et al., 2001a). In addition, sugarcane NDF digestibility may have been less affected by negative associative effects of non-fiber carbohydrates in the concentrate (PEREIRA; ARMENTANO, 2000). Thus, the lower DM intake in heifers fed the $42 \%$-NDF sugarcane diet (SC42) may have been compensated for the higher digestibility of the NDF, resulting in similar weight gains across dietary treatments (Table 3). Santos et al. (2011) evaluated the effect of different forage sources including corn silage, sorghum silage, sugarcane silage, and fresh sugarcane on the performance of dairy cows under tropical conditions. The authors reported that dry matter and organic matter digestibility were similar for corn silage, sorghum silage, and sugarcane silage, reinforcing the importance of the high digestibility of the sugarcane used in rearing and milking diets. However, milk yield was lower in cows fed sugarcane silage and fresh sugarcane diets, underlining the need for adjusting concentrate levels to support high milk production.

Using the same sugarcane variety as in this study, Andrade and Pereira (1999) reported that NDF digestibility decreased from $43.7 \%$ for corn silage to $22.5 \%$ for sugarcane in Holstein heifer diets. In high-yielding lactating cows fed concentraterich diets, Correa et al. (2001a) reported NDF digestibility values of $\sim 20 \%$ for sugarcane and double of that for corn silage. However, the low sugarcane NDF digestibility was offset by the high digestibility of the non-fiber carbohydrate fraction (Table 4) (ANDRADE; PEREIRA, 1999; CORREA et al., 2001a). The main nutritional limitation of sugarcane is the low NDF digestibility, whereas its main advantage is the high digestibility of sucrose, much higher compared to the starch digestibility of corn hybrids with vitreous endosperm used for ensilage in Brazil (CORREA et al., 2001b).

Despite the small particle size of the sugarcane forage used in this study, no symptoms of ruminal acidosis were observed. In fact, despite its small 
particle size, chopped sugarcane has been shown to have high physical effectiveness (ARMENTANO; PEREIRA, 1997; ANDRADE; PEREIRA, 1999; SÁ NETO et al., 2014; KHAN et al., 2016). The low digestibility of NDF may be related to the physical characteristics of fiber, which requires increased chewing activity to reduce the size of digesta particles passing through the reticulo-omasal orifice (SÁ NETO et al., 2014). Thus, concentrate-rich diets with sugarcane have the potential to be formulated with low percentage of forage dry matter.

Rumen $\mathrm{pH}$ was lower than previously reported for cattle fed sugarcane diets (PRESTON; LENG, 1981; LUDOVICO; MATTOS, 1997; GARRET et al., 1999; RIBEIRO et al., 2015) and there was no significant difference in ruminal fluid $\mathrm{pH}$ between dietary treatments. Ruminal $\mathrm{pH}$ correlates with the intake of DM. In this study, the $\mathrm{pH}$ was higher than expected for a diet with large amounts of soluble carbohydrates. This indicates the efficiency of the sugarcane NDF in maintaining high ruminal $\mathrm{pH}$

\section{Conclusion}

In this study, $330-420 \mathrm{~g}$ of sugarcane NDF/ $/ \mathrm{kg}$ of dry matter was sufficient to support the growth of Holstein heifers without adversely affecting ruminal parameters.

\section{References}

ANDRADE, M. A. F.; PEREIRA, M. N. Performance of Holstein heifers on fresh sugarcane as the only dietary forage. Journal of Dairy Science, Madison, v. 82, n. 91, 1999. Supplement 1.

ARMENTANO, L. E.; PEREIRA, M. N. Measuring the effectiveness of fiber by animal response trials. Journal of Dairy Science, Madison, v. 80, n. 7, p. 1416-1425, 1997.

ASSOCIATION OF OFFICIAL AGRICULTURAL CHEMISTS - AOAC. Official methods of analysis. $15^{\text {th }}$ ed. Arlinton: Association of Official Analytical Chemists, Inc., 1990. v. 1, $771 \mathrm{p}$.

CAETANO, G. A. de O.; CAETANO JÚNIOR, M. B.; OLIVEIRA, M. D.; SOCREPPA, L. M. Cana de açúcar na alimentação de novilhas leiteiras. PUBVET, Maringá, v. 10, n. 10, p. 766-778, 2016.

CORREA, C. E. S.; PEREIRA, M. N.; RAMOS, M. H.; OLIVEIRA, S. G.; OTA, M.; Performance of dairy cows fed corn silage differing in kernel texture or sugarcane as the dietary forage. Journal of Dairy Science, Madison, v. 83, p. 119, 2001a. Supplement 1.

CORREA, C. E. S.; SHAVER, R. D.; PEREIRA, M. N.; LAUER, J. G.; KOHN, K.; Correlation between texture and in situ degradation of corn grain. Journal of Dairy Science, Madison, v. 84, p. 418, 2001b. Supplement 1.

CURTIS, G.; MCGREGOR ARGO, C.; JONES, D.; GROVE-WHITE, D. The impact of early life nutrition and housing on growth and reproduction in dairy cattle. Plos One, San Francisco, v. 13, n. 2, p. 1-20, feb. 2018.

DRACKLEY, J. K. Calf nutrition from birth to breeding. Veterinary Clinics of North America: Food Animal Practice, Philadelphia, v. 24, n. 1, p. 55-86, 2008.

ETTEMA, J. F.; SANTOS, J. E. Impact of age at first calving on lactation, reproduction, health and income in first-parity Holsteins on commercial farms. Journal of Dairy Science, Madison, v. 87, n. 8, p. 2730-2742, 2004.

GARRET, E. F.; PEREIRA, M. N.; NORDLUND, K. V.; ARMENTANO, L. E.; GOODGER, W. J.; OETZEL, G. R. Diagnostic methods for the detection of subacute ruminal acidosis in dairy cows. Journal of Dairy Science, Madison, v. 82, n. 6, p. 1170-1178, 1999.

KEOWN, J.F.; EVERETT, R.W. Effect of days carried calf, days dry, and weight of first calf heifers on yield. Journal of Dairy Science, Madison, v. 69, n. 7, p. 18911896, 2004.

KHAN, M. A.; BACH, A.; WEARY, D. M.; VON KEYSERLINGK, M. A. G. Invited review: transitioning from milk to solid feed in dairy heifers. Journal of Dairy Science, Madison, v. 99, n. 2, p. 885-902, 2016.

LAMMERS, B. P.; BUCKMASTER, D. R.; HEINRICHS, A. J. A simple method for the analysis of particle sizes of forage and total mixed rations. Journal of Dairy Science, Madison, v. 79, n. 5, p. 922-928, 1996.

LAMMERS, B. P.; HEINRICHS, A. J.; KENSINGER, R. S. The effects of accelerated growth rates and estrogen implants in prepubertal Holstein heifers on growth, feed efficiency, and blood parameters. Journal of Dairy Science, Madison, v. 82, n. 8, p. 1746-1752, 1999.

LASCANO, G. J.; VELEZ, M.; TRICARICO, J. M.; HEINRICHS, A. J. Nutrient utilization of fresh sugarcane-based diets with slow-release nonprotein nitrogen addition for control-fed dairy heifers. Journal of Dairy Science, Madison, v 95, n. 1, p. 370-376, 2012. 
LUDOVICO, A.; MATTOS, W. R. S. Avaliação de dietas a base de cana-de-açúcar-de-açúcar e diferentes níveis de sementes de algodão. Revista da Sociedade Brasileira de Zootecnia, Viçosa, v. 26, n. 2, p. 403-410, 1997.

MARIZ, L. D. S.; VALADARES FILHO, S. C.; DETMANN, E.; PEREIRA, O. G.; PEREIRA, L. G. R.; MARCONDES, M. I.; SANTOS, S. A.; VILLADIEGO, F. A. C.; ZANETTI, D.; PRADOS, L. F.; NUNES, A. N. Intake and ruminal digestion determined using omasal and reticular digesta samples in cattle fed diets containing sugar cane in natura or ensiled sugar cane compared with maize silage. Livestock Science, Amsterdam, v. 155, n. 1, p. 71-76, 2013.

MORAES, K. A. K.; VALADARES FILHO, S. C.; MORAES, E. H. B. K.; PINA, D. S. Calcium oxide levels in sugarcane silage, fresh sugarcane or corn silage for feedlot Nellore heifers. The Journal of Animal and Plant Science, Pakistan, v. 25, n. 4, p. 989-996, 2015.

PEREIRA, M. N.; ARMENTANO, L. E. Partial replacement of forage with non-forage fiber sources in lactating cow diets. II. Digestion and rumen function. Journal of Dairy Science, Madison, v. 83, n. 12, p. 28762887,2000

PRESTON, T. R.; LENG, R. A. Utilization of tropical feeds by ruminants. In: RUCKEBUSCH, Y.; THIVEND, P. Digestive phisiology and metabolism in ruminants. Connecticut: Ed. AVI Publishng Company, Inc., 1981. cap. 30, p. 621-640.

RANGEL, A. H. N.; CAMPOS, J. M. S.; OLIVEIRA, A. S. de; VALADARES FILHO, S. C.; ASSIS, A. J. de; SOUZA, S. M. de. Performance and nutritional parameters of growing heifers fed corn silage or sugar cane with concentrate. Revista Brasileira de Zootecnia, Viçosa, MG, v. 39, n. 11, p. 2518-2526, 2010.

REYES, J.; MONTANEZ-VALDEZ，O.; GUERRA, C.; PALMA, J. Effect of sugarcane silage on productive parameters of replacement Holstein-Friesian heifers. Revista MVZ Cordoba, Córdoba, v. 19, n. 1, p. $3962-$ 3969, 2014.

RIBEIRO, R. C. O.; VILLELA, S. D. J.; VALADARES FILHO, S. C.; SANTOS, S. A.; RIBEIRO, K. G.;
DETMANN, E.; ZANETTI, D.; MARTINS, P. G. M. A. Effects of roughage sources produced in a tropical environment on forage intake, and ruminal and microbial parameters. Journal of Animal Science, Champaign, v. 93, n. 5, p. 2363-2374, 2015.

SÁ NETO, A.; BISPO, A. W.; JUNGES, D.; BERCHT, K.; ZOPOLLATTO, M.; DANIEL, J. L. P.; NUSSIO, L. G. Exchanging physically effective neutral detergent fiber does not affect chewing activity and performance of late-lactation dairy cows fed corn and sugarcane silages. Journal of Dairy Science, Madison, v. 97, n. 11, p. 70127020, 2014.

SALAH, N.; SAUVANT, D.; ARCHIMÈDE, H. Response of growing ruminants to diet in warm climates: a meta-analysis. Animal, Cambridge, v. 9, n. 5, p. 822830, 2015.

SANTOS, S. A.; VALADARES FILHO, S. C.; DETMANN, E.; VALADARES, R. F. D.; RUAS, J. R. M.; AMARAL, P. M. Different forage sources for F1 Holstein $\times$ Gir dairy cows. Livestock Science, Amsterdam, v. 142, n. 1-3, p. 48-58, 2011.

SIÉCOLA JÚNIOR, S.; BITENCOURT, L. L.; MELO, L. Q.; SILVEIRA, V. A.; LOPES, N. M.; SILVA, J. R. M.; PEREIRA, R. A. N.; PEREIRA, M.N. Despalha da cana-de-açúcar e desempenho de novilhas e vacas leiteiras. Arquivo Brasieliro de Medicina Veterinária e Zootecnia, Belo Horizonte, v.66, n.1, p.219-228, 2014.

STATISTICAL ANALYSIS SYSTEM INSTITUTE SAS Institute. SAS ${ }^{\circledR}$ User's guide: Statistics. $5^{\text {th }}$ ed. Cary: NC SAS Institute Inc., 1995. 1290 p.

VAN SOEST, P. J.; ROBERTSON, J. B.; LEWIS, B. A. Methods for dietary fiber, neutral detergent fiber, and nonstarch polysaccharides in relation to animal nutrition. Journal of Dairy Science, Madison, v. 74, n. 10, p. 35833597, 1991.

WILLIAMS, C. H.; DAVID, D. J.; IISMAA, O. The determination of chromic oxide in feces samples by atomic absortion spectrophotometry. Journal of Agricultural Science, Cambridge, v. 59, n. 3, p. 381-385, 1962. 
